\title{
Populism and nationalism revisited: A comparative study of the Spanish and Portuguese New Left
}

\section{Filipe Carreira da Silva (1) I Luca Manucci | David Veloso Larraz (1)}

Institute of Social Sciences (ICS), University of Lisbon, Lisbon, Portugal

\section{Correspondence}

Filipe Carreira da Silva, Institute of Social Sciences (ICS), University of Lisbon, Lisbon, Portugal.

Email: fcs23@ics.ulisboa.pt

Funding information

Fundação para a Ciência e a Tecnologia, Grant/Award Number: PTDC/SOCSOC/28524/2017

\begin{abstract}
Current definitions of populism are insufficiently determinate. They fail to distinguish between populism and nationalism. We propose to remedy this problem by advancing a new definition of populism as the logic of democratic resentment. We apply this new definition to a comparison between Spain's Podemos and Portugal's Left Bloc (BE), which we classify as social carriers of populism. We make two contributions to the literature. First, our findings dispute existing characterisations of the Portuguese case, which fail to distinguish between populist and nationalist claim-making. Second, our analysis undermines depictions of Podemos as the consummate populist party in Iberia: In 2015, the little studied BE was a stronger populist carrier than Podemos. The analytical framework underpinning this conclusion offers a more refined approach to populism than the alternatives and sets a higher standard for empirical replication.
\end{abstract}

KEYWORDS

Iberia, political parties, populism, resentment, social theory

\section{1 | INTRODUCTION: THE POLITICS OF DEMOCRATIC RESENTMENT IN THE WAKE OF THE GREAT RECESSION}

Despite a burgeoning literature on the topic, we still lack a clear-cut definition of populism that is both theoretically consistent and empirically applicable. Existing definitions are all-encompassing. They either offer a normative

This is an open access article under the terms of the Creative Commons Attribution-NonCommercial-NoDerivs License, which permits use and distribution in any medium, provided the original work is properly cited, the use is non-commercial and no modifications or adaptations are made.

(c) 2022 The Authors. Nations and Nationalism published by Association for the Study of Ethnicity and Nationalism and John Wiley \& Sons Ltd. 
account of populism as politics itself (Laclau, 2005) or fail to adequately distinguish between populist and other ideologically informed invocations of the people. In particular, as populist scholars have long noted (Canovan, 2005; Mény \& Surel, 2000), there is an 'ultimately confusing overlap between the concepts of populism and nationalism' (de Cleen and Stavrakakis 2017, 301), and especially, the term right-wing populism 'often conflates populism and nationalism' (Halikiopoulou \& Vlandas, 2019, p. 430).

Morphological accounts of ideology (Freeden, 1996), which underpins the influential ideational approach to populism (Mudde, 2017), are also of limited help. Instead, we need to carefully reconstruct the way in which populists contest and recontest fundamental political concepts. Populists do this according to a distinctive logic: democratic resentment. Resentment refers here not so much to an individual emotion or sentiment but rather than to an affect around which collective action is patterned against a democratic normative background. As with any affect, resentment's patterning of social and political action is not limited to ideational factors and cultural structures alone; it also includes material entities and socioeconomic structures. Methodologically, this new theoretical approach translates into a discourse analysis that identifies as populist statements that are produced according to the logic of resentment. In this article, we test this novel approach against the case of Iberia, offering a comparison between two political parties, Spain's Podemos (Podemos and Unidas Podemos-UP) and Portugal's Left Bloc (Bloco de Esquerda-BE). These parties are taken to be the regional representatives of the category of far-left political forces that, from Latin America to Europe, have toyed with populism in recent decades.

This regional focus is justified for several reasons. Despite having suffered much of the brunt of the Great Recession, comparisons of the two Iberian countries are scarce. Much attention has been devoted to the Spanish case. A cause célèbre among populist scholars, Podemos showcases the current populist wave. Much less attention has been devoted to Portugal. The few existing studies rely on mainstream definitions of populism. A case in point is Lisi and Borghetto $(2018,407)$. Their expansive definition of populism leads them not only to describe the BE as a populist party (itself a controversial claim) but also to include the Portuguese Communist Party (Partido Comunista Português-PCP) in a broad populist coalition against austerity since 2011.

This paper disputes this account of a broad left-wing populist coalition in Portugal, which we trace back to the conceptual conflation between nationalism and populism. We do this in four successive steps. First, our definition of populism and methodology is introduced. Second, we offer a historical synopsis of the two political parties, including their internal structure, ideology and strategy. Third, we present our data from a discourse analysis of the electoral manifestos produced by the BE and Podemos for general elections in 2015 and 2019. Fourth, we offer a discussion of our findings. The paper concludes with a summary of the findings and suggestions for future research.

\section{2 | THEORY AND METHODS}

This section outlines our understanding of populism and the methodology of the article. We define populism as a way of doing politics governed by the logic of democratic resentment. Populism is less a matter of finding the correct substantive content that distinguishes populist politics, such as an ideology (Mudde, 2017), a form of political mobilisation (Jansen, 2011) or a style of political communication (Kazin, 1995), than a question of identifying the correct way (or logic) that helps organise those contents. Yet, in contrast to Laclau's (2005, pp. 117-118, 147, 198) definition of populism, where the populist logic determines contents and is equated with politics itself, we suggest that contents are only partly defined by populism, which is only one logic out of many other possible logics of political action.

Why resentment and not enmity? Resentment refers not to an individual emotion or sentiment (see Rico et al., 2017) but an affect that patterns social and political action. Democratic resentment refers specifically to the affective patterning of collective action in democratic societies, in the sense of collectivities that are normatively oriented towards, and whose political institutions are organised according to, principles of popular sovereignty and equal respect (e.g., see Cramer, 2016; Demertzis, 2006; Engels, 2015). Although we claim that the logic of populism 
is the logic of resentment, not all sub-logics of resentment are populist. In fact, most forms of resentment are not associated with populism at all. There is populism when four elements occur simultaneously: a normative element (orientation to democratic norms of equality and popular sovereignty); a comparative element (sense of undeserved inferiority); a rivalry between parts (one part is deemed responsible for the undeserved suffering of the other) and a redemptive element in the form of an appeal to the restoration of democratic equality (Silva \& Vieira, 2018a: 507, 2018b). These philosophically derived conditions provide clear analytical criteria by which to distinguish between distinctively populist claims and other, non-populist political statements. In this paper, the terms 'populist' and 'populism' (e.g., 'Podemos' populism') are used to refer to this distinctive logic of action.

This definition of populism is precise enough to help us distinguish what populism is from what it is not, and it enables us to define populism not as a categorical variable with only two possible outcomes, but as a matter of degree, which allows us to determine the exact extent to which our parties act as social carriers of populism. ${ }^{1}$ Moreover, it is amenable to in-depth case studies considering both material and cultural factors while being sensitive to the distinction between two opposing types of moral relationship. On the one hand, populism can be associated with moral criticism, that is, well-reasoned and thoughtful critiques of another's actions that are restrained by a basic sense of respect. On the other hand, populism can sometimes lead to moralism, where criticism of another's actions is devoid of any consideration for that person's moral agency (McKibben, 2020).

In this paper, we measure the use of the populist logic of resentment in party manifestos from Podemos and the BE in 2015 and 2019. Our research design involves a diachronic study of these parties' populism, which enables us to document whether these parties deployed populism more or less over time, which topics increased or decreased in importance and whether there is significant cross-national variation. The period under study is 2015 and 2019, years when both Iberian democracies held general elections. This is also the only period when both the BE and Podemos, which was founded in early 2014, were among the electoral contenders.

The unit of analysis is populist statements. Even though political discourse obviously exceeds the condensed form of the manifesto-including campaigning, interviews and many other forms of political communicationelectoral manifestos nonetheless provide researchers with an easily accessible overview of the party's official position (Rooduijn \& Pauwels, 2011).

Political discourse analysis is a well-established methodology aimed at accounting for political claim-making by parties and their leadership. In recent years, it has been applied to study populism in party manifestos (Rooduijn \& Pauwels, 2011), social media (Schmuck \& Hameleers, 2019), speeches (Hawkins, 2009) and newspaper articles (Rooduijn, 2014). In this paper, we analyse political statements in electoral manifestos as the percentage of populist statements in a manifesto (Manucci \& Weber, 2017). Although more laborious than other approaches, this methodology provides the most adequate complement to our understanding of populism as the logic of democratic resentment. In particular, it is preferable to an automated content analysis, which reduces the study of populism to an account of the frequency of particular words. By contrast, our qualitative content analysis allows for the identification of distinctively populist political statements that respect all four conditions presented above: normative orientation, comparison, rivalry and redemption.

Among the populist statements identified by our content analysis, we single out three specific topics: corruption, austerity and mainstream parties. In the last decade, corruption has become a significant issue in both Iberian democracies, with important implications for institutional trust (Sanders et al., 2017; Torcal, 2014). Corruption is, of course, at the heart of the redemptive promise of a revigorated people that is yet to come: The purge of the 'corrupted' or 'polluted' elements is indispensable for the purification of the people and the realisation of true democracy. Politically, the moralising trope regarding corruption functions as a positioning rhetorical device, chastising mainstream parties (and their leaderships) as 'corrupt' and enabling populist leaders to portray themselves as 'honest'.

A second issue is austerity. The politics of austerity resonates with the populists' normative orientation towards democratic equality and popular sovereignty in opposition to liberalism and liberal constitutionalism (Pappas, 2019). In the context of the Iberian democracies in the period studied here, this is represented by the liberal 'Washington consensus' that underpins the politics of austerity implemented by the so-called Troika of lender institutions (the 
IMF, the European Central Bank and the European Commission). The Troika, however, did not have the same relationship to the two Iberian countries: While it was omnipresent in Portugal between 2011 and 2013 due to the $€ 78$ billion bailout package (Lisi et al., 2019), in Spain, its influence was only indirectly exerted through the 2012 bank bailout (Ramiro \& Gomez, 2017).

A third issue relates to the political positioning of Podemos and the BE vis à vis centre-left and centre-right political parties (Roberts, 2017). Two constitutive elements of the logic of democratic resentment help clarify what is at stake here: the sense of undeserved inferiority that one part of the people feels and the rendering one part of the people responsible (or to blame) for the undeserved suffering of the other part. Mainstream parties, especially those with experience in government, are among the preferred targets of the populists' moralising blame game.

\section{3 | POPULISM IN IBERIA}

The period between 2015 and 2019 is a crucial episode in the history of populism in Iberia. The Iberian party systems were put under pressure, particularly in Spain where several new political forces emerged across the ideological spectrum. Podemos, an outgrowth of the $15 \mathrm{M}$ anti-austerity movement of the spring of 2011 , is one such case. In Portugal, by contrast, the party system and the political system as a whole proved more resilient. The comparison between Podemos and the BE is warranted because these parties share broadly the same ideology and electorate. However, while Podemos is one of the most studied cases in the populist literature (e.g., Custodi, 2021; Gómez-Reino \& Plaza-Colodro, 2018; Katsambekis \& Kioupkiolis, 2020; Orriols \& León, 2020), there has been much less attention devoted to scrutinising the populist credentials of the BE. ${ }^{2}$

Portugal's Left Bloc was created in 1999 as the merger of three far left parties: Marxist (UDP, People's Democratic Union), Trotskyist (PSR, Revolutionary Socialist Party) and democratic socialist (Politics XXI). The resulting $B E$ is often described as a neo-Marxist, Eurosceptic and anti-system party. Notwithstanding the severity of the 2011-2013 economic crisis in the country, the Portuguese political system remained stable (Gómez-Reino \& Plaza-Colodro, 2018; Lisi, 2019). Despite sharing, with the Portuguese Communist Party (PCP), a monopoly on the political representation of the economically discontented, the BE failed to make class divisions a salient issue. ${ }^{3}$ It performed poorly in the 2011 general election (5.2\%) and even worse in the 2014 European elections (only $4.5 \%$ ). Its efforts, under the leadership of Catarina Martins, did not prevent the incumbent right-wing coalition from winning the 2015 general election with a relative majority. Nevertheless, an unprecedented deal was struck between the mainstream socialists and the radical left-the so-called geringonça (contraption)-which eventually yielded a stable government. This deal was not repeated in 2019, however.

Podemos is the institutional translation of the $15 \mathrm{M}$ Movement (or indignados) and retains much of the movement's ethos. Created with the explicit aim of 'converting indignation into political change', Podemos is seemingly the ultimate carrier of the populist logic of democratic resentment, a crucial component of which is precisely sociopolitical indignation. ${ }^{4}$ Preceded by the conservative-liberal Ciudadanos, and later followed by the right-wing Vox, Podemos is one of the main protagonists of the stress test the Spanish political system, and, in particular, its party system and political culture have been undergoing since the mid-2000s (Fominaya, 2020). Created in 2014, its history is much shorter than that of the BE. Still, both parties share a number of features. Podemos was formed via the combination of three political groupings, namely, social activists, radical left-wing political militants and academics. The party's initial adoption of an open assembly organisational form ('circles'), which was derived from the experience of the $15 \mathrm{M}$ movement (Gomez \& Ramiro, 2019), has gradually given way to a strong vertical leadership and more centralised structure (Kioupkiolis, 2016). The leadership of Pablo Iglesias, a charismatic speaker and capable media performer who has meanwhile exited politics, should also be noted (Gómez-Reino \& Plaza-Colodro, 2018).

Podemos' success story began with the 2014 European elections. With near $8 \%$ of the vote, Podemos stunned the Spanish political establishment. Its incisive activation of the class cleavage enabled it to become the fourth political force almost overnight. ${ }^{5}$ The next big test was the 2015 general election. Despite a highly disproportional 
electoral system, Podemos consolidated its position and obtained 5 million votes or $20.6 \%$ of the electoral share and 69 seats. However, negotiations with the Spanish Socialist Workers' Party (Partido Socialista Obrero Español-PSOE) a centre-left mainstream party, failed, and Podemos turned further to the left, reaching an agreement with the United Left (Izquierda Unida-IU). The explicit aim of the new Unidas Podemos (henceforth UP) coalition was that of the sorpasso, that is, to overtake the centre-left PSOE as the main progressive political force. However, the next two general elections-June 2016 and April $2019^{6}$-failed to give the new coalition the necessary votes to achieve that strategic goal. UP and the PSOE again failed to reach an agreement, and another general election was held in November 2019. This broke the political stalemate. Faced with the rapid rise of the right-wing Vox and despite their parties' disappointing electoral results (PSOE was down from 123 to 120 seats and UP was down from 42 to 35), party leaders Pedro Sánchez and Pablo Iglesias quickly reached an agreement to form a government. Podemos eventually reached power in less than 6 years since its creation, a position it still enjoys as of this writing.

\section{4 | FINDINGS: BE's AND PODEMOS' PARTY MANIFESTOS, 2015-2019}

This section presents the findings of our study of the BE's and Podemos' electoral manifestos for the 2015 and 2019 general elections. To the best of our knowledge, this is the first time such a longitudinal comparison has been made between the two parties. In particular, we focus on two elements: how often and in what way the two parties function as carriers of populism by reference to three issues: corruption, austerity and centre-right and centre-left mainstream parties.

We analyse four electoral manifestos, two from each party. The years covered are 2015 and 2019. We have selected these manifestos for three main reasons. First, it enables us to study manifestos written in different countries but approximately at the same time, which makes the comparison more meaningful as both elections take place against the same international background conditions. Second, in 2015, both the BE and Podemos dispute elections as challenger parties and in the aftermath of a deep economic crisis, two factors that have been associated with populist discourse. Third, the political position of the BE shifts between 2015 and 2019. After 4 years lending parliamentary support to the minority socialist government led by Costa, the BE contests the 2019 general election less as a challenger and more as an incumbent. In order to better capture the party dynamics involving the BE and Podemos in their respective countries, we analyse the electoral manifestos of two other parties: the PCP and the IU. Given the latter's fusion with Podemos in 2016, we restrict our analysis to 2015 (see Appendix S3).

The content analysis of the BE's and Podemos' manifestos was performed by the authors according to the codebook presented in Appendix S1, which details the operationalisation of populism, of each topic analysed and of the unit of analysis. Appendix S2 reports every coded statement with its own translation in English and comments concerning the reasons for being coded as populist or as belonging to a certain topic, making the analysis fully transparent and replicable. The analysis reveals both the level of populism in each manifesto (the percentage of populist statements in the text), as well as the salience of three key issues: corruption, austerity and their positioning relative to mainstream parties. The results are summarised in Figure 1.

\section{1 $\quad$ BE and Podemos in 2015}

In 2015, the level of populist discourse in the BE's electoral manifesto is higher than that found in Podemos's: 5.3\% against $4.2 \%$. This is the first surprising finding of our analysis.

We can now identify exactly how this difference between the BE and Podemos manifested itself in 2015. The opposition between people and elite helps structure the BE's 2015 manifesto. It is worth recalling that, prior to 


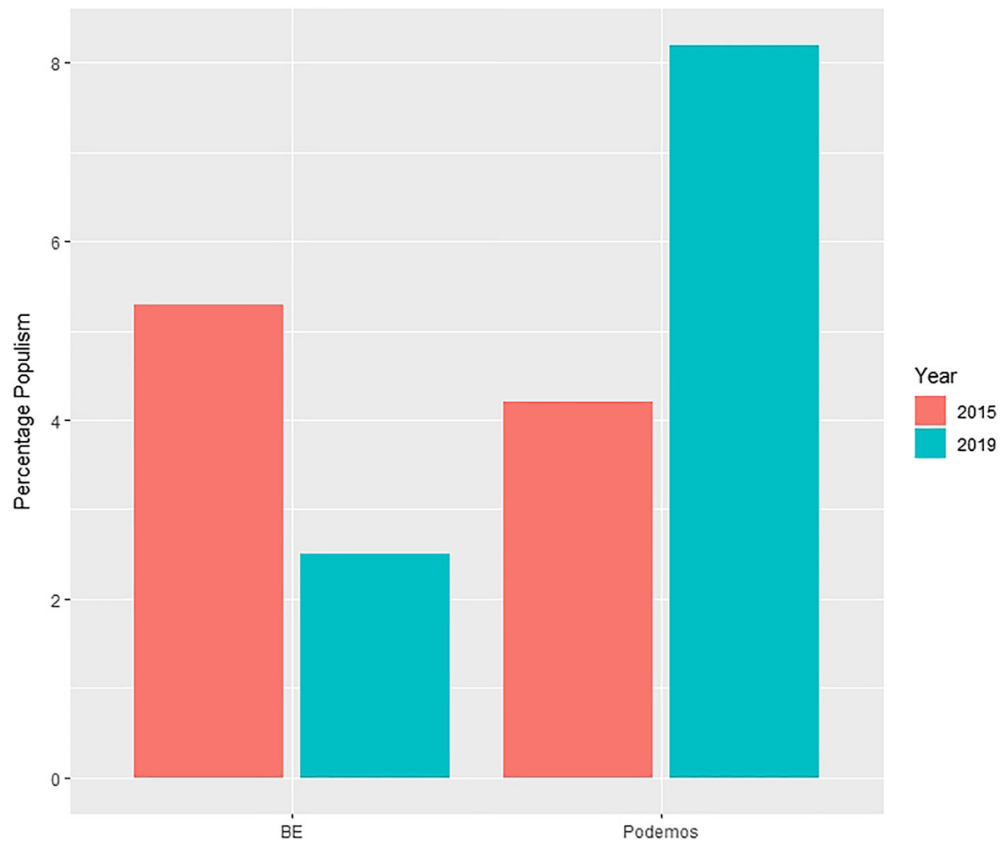

FIGURE 1 Levels of populism in the manifestos of Podemos and the BE (2015-2019) [Colour figure can be viewed at wileyonlinelibrary.com]

the 2015 election, the party was in opposition. In the wake of the 2011-2013 crisis, the BE, like its left-wing rivals the PCP, was intent on capitalising on popular discontent with the Troika's austerity. The Troika's conditionality is depicted as both unnecessary and unfair to the Portuguese people, in whose name the party now tries to speak. In particular, the BE identifies 'the people' with 'disadvantaged families' (p. 14), 'unemployed, precarious and young people' (p. 42) and unprotected citizens (p. 34). The working class, equated with 'the great majority of the Portuguese', is described as having experienced 'undeserved suffering' (p. 10). Straight from the populist playbook, this is accompanied by the vilification of the 'Right' as the 'elite', which is opposed to the 'population' and universal social rights (p. 14).

Euroscepticism, notably absent from the party's message since its founding, is now a central feature of its discourse. The BE's 2015 electoral manifesto actually begins with a reference to the 'Europe of peoples' (p. 3; see also p. 63). Putting the people at the centre of the European project while attacking the EU institutions, as well as 'the power of Berlin' (p. 3), portrayed as responsible for the underserved suffering of the people, who are said to be strapped in an 'austerity straight jacket' (p. 4), is a very clear example of populist rhetoric. A European-level popular referendum on the Treaty of Budgetary Consolidation is proposed as a response to the European peoples' 'disobedience'. This is yet another classic populist theme: The constituent power of the people takes precedence over constitutions and international treaties, which are denigrated as instruments of the liberal constitutional order and responsible for a so-called 'austericide' (p. 10).

Written within months of the party's foundation, the 2015 electoral manifesto is Podemos' first public articulation of the party's position in the context of Spanish electoral politics. Crucially for our purposes here, this is also where we see the quintessential populist opposition between people and elite being deployed for the first time. It introduces the populist opposition between la gente (the humble many) and los poderosos (the powerful few), which remain 'indifferent' and oblivious as to the problems of the common folk (p. 11), in order to challenge Spain's constitutional order and regenerate democracy (p. 166). This challenge to the liberal constitutional order is made in typically populist terms: It is articulated in the name of the people, justified by reference to the corruption 
of the few and focused on protecting universal social rights (p. 13). Like the BE's, Podemos's 2015 manifesto also claims to speak in the name of the 'Europe of the peoples' (pp. 59-60) against the EU's institutions. Moreover, populism's typical redemptive future-oriented temporality is also found in Podemos's 2015 manifesto. A case in point is its proposal for ley de paredes de cristal (p. 166), aimed at the urgent democratic regeneration of the state apparatus.

Let us now consider how the logic of democratic resentment is deployed to address more specific issues, namely, corruption, austerity and mainstream parties. Podemos thematises corruption in distinctively populist terms more often than the BE: six and three statements each or $0.46 \%$ and $0.35 \%$, respectively. At stake here is the moralist way Podemos addresses this theme. Consider Podemos' proposal to eliminate the 'privileges' of elected officials. The implication is that the 'political' nature of high-level official positions equates to corruption and abuse. This connects with Podemos' claim that institutions should serve the people, something to be achieved through greater transparency (p. 166-167) and the elimination of the privileges of 'the political caste' (p. 162-165). The solution is 'technical' staff, which ties in with the well-known elective affinity between populism and technocracy in their shared suspicion of representative democracy (p. 162). Likewise, the BE adopts a moralist language that pits the virtuous many against the corrupt few. A case in point is the reference, when discussing the issue of national debt, to the EU's 'extortion' of the European peoples (p. 3). Debt restructuring is likewise an object of moralism on the part of the BE. An 'audit' is proposed to determine the 'illegitimate part' of what is owed, raising suspicion on the debt as a whole (p. 5).

Let us now turn to the politics of austerity. While explicit mentions of the Troika are rare in both manifestos, the BE is more vocal in its criticisms of the Troika's austerity policies than Podemos. Running as a challenger in the 2015 election, in the aftermath of the implementation of the 2011 Memorandum of Understanding between Portugal and the so-called Troika of lender institutions, the BE not only targets the Troika itself but repeatedly associates it with the right-wing coalition government. By contrast, populist critiques of the Troika are almost absent from Podemos' manifesto (but see pp. 48-49). Given that the Troika and its austerity agenda only effected Spain in an indirect fashion, this is unsurprising.

Let us conclude with the criticisms of mainstream centre-left and centre-right parties. The BE is much more vocal than Podemos. While the BE targets mainstream parties in no less than 11 occasions, Podemos does it only twice. Unsurprisingly, the BE focuses most of its attacks on the right-wing coalition, portrayed as guilty by association with the Troika's austerity. However, it also tries to distance itself from the PS using a similar rhetorical strategy; that is, it associates the socialists not only with the political right in general but with the government and the Troika specifically (e.g., p. 4). This, however, did not stop the BE from joining forces with the socialists to prevent a second term of the right-wing government. In Spain, by contrast, Podemos makes no distinction in their criticism of the austerity policies of both the People's Party (Partido Popular-PP) and PSOE, positioning the party as the only real anti-austerity alternative, but making far fewer populist claims against mainstream parties.

\section{2 $\quad$ BE and Podemos in 2019}

In 2019, Unidas Podemos's discourse was more populist than the BE: $8.2 \%$ against $2.5 \%$, respectively. The populism that characterised the BE's 2015 manifesto gives way to a markedly different political message. The BE's 2019 manifesto is populated with terms such as 'responsible', 'trustworthy' and 'loyal'. It also includes a detailed list of achievements and promises, namely, related to the 'climate emergency', transport policy, energy policy challenges and the like (p. 7). The main message is clear. The party is here to prestar contas, that is, to take responsibility (and credit) for the years of support of the government, as a loyal and trustworthy partner (p. 30). There are a few instances, however, where the BE still deploys populism in 2019. For example, it claims to fight austerity in the name of 'those who live off their work and their pension' (p. 6), common people (p. 29), from the attacks of the right and its 'corporate vampirisation' (p. 41) and from the impositions of Brussels (pp. 31-32). Moreover, regarding 
corruption, it uses the opposition between the plebs and the elite, the latter accused of 'robbing' banks with the help of the right-wing government. Likewise, it admonishes the electorate of the dangers of an absolute majority by the socialists as the 'swamp where corruption hides' (p. 125).

Unidas Podemos' 2019 electoral manifesto is not only significantly more populist than the BE's manifesto for the same year; it is the most populist of all four manifestos. It begins with the opposition between the many, which the party claims to represent-that is, young people, women and pensioners (p. 5)-and the few-that is, politicians (pp. 58, 59), the super-rich (p. 107) and economic powers with fiscal privileges (p. 19). The party's goals are to 'conquer democracy' by putting institutions 'at the level of its people' (p. 53), reverse the austerity policies that have devastated 'the social fabric of our societies' (p. 102) and restore popular legitimacy (p. 107). The so-called 'vulture funds' (pp. 21-22) embody UP's antagonism with the elite. The bank bailout is still a live issue; it is used to foster a sense of resentment and imply that Podemos is the only force that can fight against the interests of the elites (pp. 38, 54, and 110).

Let us now turn to some of the more specific issues that are the focus of the politics of democratic resentment. With regards to corruption, Unidas Podemos mentions this issue much more frequently than the BE: 13 populist statements in UP's manifesto refer specifically to corruption, against only one by the BE. Indeed, a moralist discourse focused on the opposition between corrupt elites and honest, humble groups, such as young people, women and pensioners, pervades Unidas Podemos' manifesto (e.g., pp. 53, 93). While the BE is now noticeably less focused than Unidas Podemos on corruption, corruption is still deployed to expose the lack of transparency in the relationship between politics and business (p. 113).

Let us now consider austerity. Six years after its departure from Portugal, the Troika is no longer a realistic target for the BE's politics of democratic resentment. In the three occasions, the BE mentions the Troika and its policies; the problem is less the Troika per se than that mainstream parties accepted and implemented its austerity measures: in other words, the Troika's legacy. A couple of criticisms of the Troika itself, however, still appear in UP's manifesto.

Finally, in 2019, less than $1 \%$ of statements address mainstream parties: $0.82 \%$ (or 10 statements) and $0.81 \%$ (or 8 statements) for the BE and Unidas Podemos, respectively. Beginning with Unidas Podemos, the PSOE is portrayed as an untrustworthy party. Together with the PP, the PSOE has put the interests of the banks ahead of those of Spanish citizens (p. 108) and will continue to do so unless it is controlled by Podemos from within the government (p. 6). Podemos therefore claims that its participation in government is essential to democratic regeneration, the 'constitutionalisation of popular sovereignty' (p. 60) via participatory legislative initiatives and the reinforcement of the people's power over the legislative branch of the government (p. 61). Crucially, Unidas Podemos proposes to revert the 2015 'express reform' of the Constitutional Court by the PP in order to bring it back under the people's control; the people, not political parties or the legal constitutional establishment, is understood as the primary source of political sovereignty (p. 67). Meanwhile, in Portugal, the $\mathrm{BE}$ presents its agreement with the socialists as a positive experience and one that should be repeated. Criticism of mainstream parties thus largely targets centre-right and right-wing forces, rather than the PS, with the former deemed responsible for the undeserved suffering of the many, often in association with the Troika's neoliberal legacy.

\section{5 | DISCUSSION}

We can now discuss our findings. First, what explains the fact that, in 2015 , the BE is a stronger populist carrier than Podemos? Second, what accounts for the reversal of this situation 4 years later? Let us begin with the former question, arguably the most surprising finding.

Our proposed explanation involves two main components. On the one hand, there is the competition between the BE and the PCP. The existing literature, using a similar methodology to that used here, suggests that this 
relationship mirrors the Spanish case, ${ }^{7}$ with the two parties forming a broad populist front of the new and old left (Lisi \& Borghetto, 2018). However, we do not consider the Portuguese Communist Party to be a carrier of populism. In fact, the 2011 and 2015 manifestos of the PCP are notable for their absence of populist statements. ${ }^{8}$ Our analysis of the electoral manifestos of the PCP and the BE suggests that the relationship between the two is defined by a competition between populism and non-populism. As our definition makes clear, references to popular sovereignty (the normative element of the logic of democratic resentment) are only instances of populism when accompanied by the three other elements: a perception of undeserved inferiority emerging out of a social comparison with other groups; the establishment of a rivalrous relationship between the suffering part and the part deemed responsible for that suffering and a redemptive solution to this profound emotional pain through the swift fulfilment of the democratic promise. In the case of the communists, these are absent. This suggests that the numerous references to the people in the communists' manifesto have a different, non-populist origin, most likely in the party's nationalism (Neves, 2010). As discussed in Greenfeld and Wu (2020), the relationship between nationalism and left-wing parties is particularly complex, and in this regard, we share the view of Conversi (2020), who claims that nationalism and patriotism have remained a prerogative of the right, although it should not necessarily be so. Indeed, our study confirms that the left has maintained an ambiguous relationship with nationalism but is not alien to it. The result is a combination of historical materialism and nationalist elements aimed at preventing international capital and its agents from exploiting the 'Portuguese people'. This exploitative relation, however, is not described as a moralised opposition between the many and the few. Instead, the exploitation of the 'Portuguese people' is described according to a Marxist view of history as propelled by class struggle. The 'Portuguese people' is, in fact, a moniker for 'Portuguese workers', whose class interests are defined in systemic opposition to international capitalism. As our empirical analysis shows, however, this was not the case with the Portuguese communists.

This does not mean, of course, that populism and nationalism cannot be articulated together. Nationalism can be populist. This is broadly in line with the recent attempt by de Cleen and Stavrakakis (2017) to clarify what separates populist from nationalist discourses and how they can be articulated (Brubaker, 2020). Yet, for nationalism to be populist, a nationalist ideological project needs to be articulated with the logic of democratic resentment. Here, we part ways with De Cleen and Stavrakakis and recent applications of their model (see, e.g., Casado, 2020). By describing populism as functioning in a bottom-up vertical axis, and nationalism along an in/out horizontal axis, they unduly reduce both political phenomena for the sake of conceptual purity. Nationalism is more than a mere political logic that opposes members to non-members of a nation-state (Chernilo, 2020, pp. 1074-1076); it is an ideology that does not operate along a single axis, but rather across several dimensions, including transnational links of belonging. In turn, populism involves more than vertical appeals to the people as plebs; the populist 'othering' of elites represents economic, political and cultural elites as 'on top' as well as 'outside'. Furthermore, de Cleen and Stavrakakis (2017) distance themselves from Laclau's original claim that populism is governed by the logic of enmity: Hatred for the Other is here (rightly) reserved for nationalism (p. 311). However, they fail to make the next logical step, leaving the following question unanswered: If enmity does not drive populism, what does? A vague remark concerning the populists' 'animosity toward the elite' is as far as they go (de Cleen \& Stavrakakis 2017, 312). What this 'animosity' is, what it entails and how it differs from enmity is unexplored. The alternative presented in this paper-the logic of democratic resentment-goes a step further in specifying the populists' 'animosity', and the example of the Portuguese radical left parties illustrates the need for a clear conceptual distinction between populism and nationalism.

In sum, the party dynamics in the Portuguese Left are better characterised by competition between a neoMarxist party that acts as a carrier of populism and a Marxist-Leninist party, which does not. The BE's populism needs to be re-examined in this new light. In particular, our analysis suggests the moralistic tone deployed in corruption charges against political and economic elites, the chastising of international organisations responsible for the politics of austerity and the strident criticisms of the incumbent centre-right coalition for being complicit with the externally imposed neoliberal reforms should be understood as evidence of an attempt to articulate a distinctive political discourse to that of the communists. 
The BE's populist language is not only explained by its competition with the communists, however. This brings us to the second component of our explanation. The effects of the economic crisis, with its income distribution consequences, were still visible in 2015 and shaped that year's general elections in Portugal and Spain. Part of the explanation for BE's populism resides precisely in the party's attempt to give a new meaning to the economic cleavage as the moralised opposition between the privileged few and the vulnerable many. The BE's moralism sits in a long tradition of progressive Utopianism. Yet these new Puritans of the left, perhaps because they are more secular than earlier progressives, are also more extreme. The BE's view of social justice has little place for forgiveness or grace. Instead, it is focused on purity and atonement. What is notable about this political project is that it eventually produces an even more populist manifesto than Podemos. All this points, if we were to generalise this finding beyond Iberia, to the impact that externally imposed conditionality has on national politics. After all, the Troika is the primary target of the BE's populist chastising, along with its domestic associates, the coalition government that not only failed to protect the virtuous and helpless people but also shared the Troika's ideological preferences for flexible labour markets, reduced public expenditure and welfare state retrenchment. Such 'betrayal' could not go unpunished, a point stressed in the BE's 2015 manifesto. By contrast, Podemos' more limited targeting of the Troika but insistence upon more general rebukes of austerity, points to the advantage of a less direct and visible intervention by international lenders in avoiding a reaction to their agenda. In short, Iberia offers an instructive example of the unintended effects of externally imposed conditionality, as well as of the competition between populist and nationalist carrier groups. By extending the analysis to 2019, we are able to capture important developments in this picture.

In 2019, we find a reversal of positions vis à vis 2015. Whereas the BE almost abandons the logic of democratic resentment, Podemos becomes an even stronger populist carrier. Why? The first reason relates to whether the parties are in opposition or in power. While Podemos runs in the two elections as an opposition party, this is not the case for the BE. In 2019, it runs as an incumbent of sorts. Giving credence to the inclusion-moderation thesis for populist parties in coalition governments (Schwörer, 2021), the decrease in populist statements between 2015 and 2019 is partly explained by the party's experience with the geringonça. In addition, party dynamics lost salience as both the PCP and the BE supported the geringonça. As a result, the Puritanical tone of 2015 was replaced by a profusion of numbers, tables, graphs and maps.

The second reason for the reversal of positions can be traced back to a central feature of the logic of resentment. Just as Weber's carrier groups can both promote certain pre-existing social values and crystallise those values, populist carriers use resentment as a strategic instrument and a source of identity. This helps explain why some parties, such as the $\mathrm{BE}$, can readily abandon populism while for others, such as Podemos, this is not a realistic option. The crystallisation of populist values is a core component of the party's institutional identity. Our content analysis illustrates this. Already in 2015 , but even more so in 2019 , democratic resentment is mobilised to attribute responsibility, if not blame, for the undeserved suffering of the victims of the economic crisis. Indignation with income disparity and increasing labour market precariousness is fuelled by a moralistic discourse targeting corruption. Indeed, the opposition between the 'corrupt' few and the 'honest' 'hard-working' many is perhaps the single most important trait of Podemos' 2019 manifesto-the most populist of all our manifestos.

Podemos' manifestos distinguish themselves from the BE's for other reasons too. Podemos', more than the BE's, embody the global 'populist revolt' of the 2000s. The 2008 financial crisis and the Great Recession exposed the interstices of the global system of power, a system whose capitalist and liberal dimensions can be traced back at least to the nineteenth century. Unsurprisingly, this is also when populism emerges as a modern political phenomenon. The logic of democratic resentment has, of course, changed over the last century. Yet, in Podemos' electoral manifestos, it retains its basic oppositional stance to liberalism and representative democratic systems. Historically, populists have associated the idea of sovereignty as an empty seat of power with an ideological attempt to render the people impotent and hide the fact that the state is dominated by the elite. The belief that sovereignty should reside directly with the people, and that any representative mediation is by definition an infringement of the popular 
will, has been a constitutive element of Podemos' identity from the start. Even in power, the party has not relinquished it. Now, in government with the PSOE, it has continued to represent the people against los poderosos.

\section{6 | CONCLUSION}

The main contribution of the paper is its new theoretical-methodological approach to the study of populism. As our empirical analysis makes clear, existing conceptualisations of populism are insufficiently determinate. For instance, they fail to distinguish populism from other political phenomena such as nationalism. The conceptual conflation between populism and nationalism is not only a problem that has long afflicted populist scholarship. As the latest exchange between de Cleen/Stavrakakis and Brubaker shows, the relation between populism and nationalism remains an 'important recent focus of contestation' (Brubaker, 2020, p. 45) to this day. Despite their best efforts, the fact is that neither a Laclau-inspired discourse theoretical approach nor Brubaker's ontic approach is truly satisfactory: the former because of its tendency to 'textualise' the world and the second because it abandons the important goal of conceptual clarification for an 'impure' inductive definition (Brubaker, 2017, 2020, p. 60). As a result, both fail to distinguish populism from ideologies, such as Marxism or nationalism, or indeed from their intersection, Marxist nationalism, which also claim to speak in the name of the people. Populist invocations of the figure of the sovereign people, however, are made under very specific conditions. The logic of democratic resentment provides a theoretically consistent and empirically applicable specification of what these conditions are a normative orientation to democratic norms of equality and popular sovereignty; a comparative sense of undeserved inferiority; a rivalry between parts whereby one part is deemed responsible for the undeserved suffering of the other and a redemptive element in the form of an appeal to the restoration of democratic equality.

This conceptual clarification has ample consequences. First, it provides a better understanding of party dynamics between populist parties and other political forces. In the case of Portugal, it helps correct existing characterisations of the party dynamics on the left. Our findings dispute the existence of a broad populist left-wing front. Instead, our study points to an ongoing competition between a populist carrier, the BE and a traditional Marxist-Leninist party, which frequently evokes the figure of the sovereign people as part of its nationalist rhetoric. Second, it contributes to a better understanding of populist carrier groups themselves. As the case of Iberian populisms illustrates, the logic of democratic resentment helps pattern collective action in a range of ways, from the instrumental to the existential. This feature complements the inclusion-moderation thesis for populist parties in coalition governments and helps account for both the surprising finding that in 2015 Podemos was a less prominent populist carrier than the little studied BE and for the reversal of these positions in 2019.

Our study brings clarity to how populism acts, both in terms of its logic and in terms of its identitarian versus strategic manifestations. It also opens up important questions requiring further study, a few of which can be highlighted here. Our reconceptualisation of populism has allowed us to separate between populism and (Marxist) nationalism. However, populism and nationalism are not necessarily incompatible. More attention needs to be given to the conditions-including long-term, historical political resentments-for the articulation among the two, with the Catalan independence movement and Vox providing particularly relevant cases for the study of populist nationalism. Relatedly, further investigation is needed of the conditions under which a movement, force or party moves from using populist discourse to being populist.

\section{ACKNOWLEDGEMENT}

We thank Mónica Brito Vieira, Catherine Moury, and Joe Davidson for their valuable comments and help revising the document. All remaining errors are our own. This article was funded by national funds through FCT - Fundação para a Ciência e a Tecnologia, I.P. - as part the project PDTC/SOC-SOC/28524/2017. 


\section{ORCID}

Filipe Carreira da Silva (1) https://orcid.org/0000-0003-2459-0802

David Veloso Larraz (10) https://orcid.org/0000-0001-6752-3787

\section{ENDNOTES}

${ }^{1}$ On Weber's notion of carrier group (Trägerschichten), see Weber (1958).

${ }^{2}$ Katsambekis and Kioupkiolis (2020) do not include the BE in their analysis of left populist parties in Europe, and Gómez-Reino and Plaza-Colodro (2018) report very low levels of populism for the BE in 2011. A partial exception is Lisi and Borghetto (2018). In sum, most of the existing literature does not recognise the BE as a populist party. By contrast, it is not possible to find any literature that does not consider Podemos in populist terms.

${ }^{3}$ Besides class, the BE has chosen to explore single-issue politics rather than activate societal cleavages, namely, the religious and the centre-periphery cleavages. On economic globalisation and societal cleavages more generally, see Rodrik (2018). Regarding Iberia, Bauluz et al. (2021) show the class cleavage to be less salient in Spain than in Portugal.

${ }^{4}$ The quote comes from the 14 January 2014 manifesto that gives rise to Podemos as a political force.

${ }^{5}$ On the income/social class cleavage as a key factor behind the emergence of the $15 \mathrm{M}$ movement and Podemos, see Bosch and Durán (2019).

${ }^{6}$ Occurring in the aftermath of the 2017 Catalan independence referendum, this election failed to give an absolute majority to any political force, with UP dwindling even further to $14.31 \%$ (with 42 seats). This result questions the role of the strong centre-periphery cleavage in Spain. See Alonso and Rovira Kaltwasser (2015).

7 Our analysis of IU's 2015 electoral manifesto found a moderate level of populism: $2.26 \%$ or 39 populist paragraphs out of 1,722. See Appendix S3.1.

${ }^{8}$ With less than $1 \%$ populist paragraphs, the level of populism of this manifesto is not significant. See Appendix S3.2.

\section{REFERENCES}

Alonso, S., \& Rovira Kaltwasser, C. (2015). Spain: No country for the populist radical right? South European Society and Politics, 20(1), 21-45.

Bauluz L, Gethin A, Martinez-Toledano C, and Morgan M (2021) Historical political cleavages and post-crisis transformations in Italy, Spain, Portugal and Ireland, 1953-2020, Working Paper 2021/01, World Inequality Lab, https://halshs.archivesouvertes.fr/halshs-03131155/document

Bosch, A., \& Durán, I. M. (2019). How does economic crisis impel emerging parties on the road to elections? Party Politics, 25(2), 257-267.

Brubaker, R. (2017). Why populism? Theory and Society, 46(5), 360-367.

Brubaker, R. (2020). Populism and nationalism. Nations and Nationalism, 26(1), 44-66.

Canovan, M. (2005). The people. Polity Press.

Casado, J. A. (2020). Articulations of populism and nationalism. European Politics and Society, 21(5), 566.

Chernilo, D. (2020). Beyond the nation? Sociology, 54(6), 1072-1,087.

Conversi, D. (2020). The left and nationalism: From the French Revolution to the Anthropocene. In L. Greenfeld \& Z. Wu (Eds.), Research handbook on nationalism (pp. 34-52). Edward Elgar.

Cramer, K. J. (2016). The politics of resentment. University of Chicago Press.

Custodi, J. (2021). Nationalism and populism on the left: The case of Podemos. Nations and Nationalism, 27, 705-720.

de Cleen, B., \& Stavrakakis, Y. (2017). Distinctions and articulations. Javnost - The Public, 24, 301-319.

Demertzis, N. (2006). Emotions and populism. In S. Clarke, P. Hoggett, \& S. Thompson (Eds.), Emotions, politics and society (pp. 103-122). Palgrave Macmillan.

Engels, J. (2015). The politics of resentment. The Pennsylvania State University.

Fominaya, C. F. (2020). Democracy reloaded. Oxford University Press.

Freeden, M. (1996). Ideologies and political theory. Oxford University Press.

Gomez, R., \& Ramiro, L. (2019). The limits of organizational innovation and multi-speed membership. Party Politics, 25(4), 534-546.

Gómez-Reino, M., \& Plaza-Colodro, C. (2018). Populist euroscepticism in Iberian party systems. Politics, 38(3), 344-360.

Greenfeld, L., \& Wu, Z. (2020). Research handbook on nationalism. Edward Elgar.

Halikiopoulou, D., \& Vlandas, T. (2019). What is new and what is nationalist about Europe's new nationalism? Explaining the rise of the far right in Europe. Nations and Nationalism, 25, 409-434.

Hawkins, K. A. (2009). Is Chavez populist? Comparative Political Studies, 42(8), 1040-1067. 
Jansen, R. S. (2011). Populist mobilization. Sociological Theory, 29(2), 75-96.

Katsambekis, G., \& Kioupkiolis, A. (2020). The populist radical left in Europe. Routledge.

Kazin, M. (1995). The populist persuasion. Basic Books.

Kioupkiolis, A. (2016). Podemos: The ambiguous promises of left-wing populism in contemporary Spain. Journal of Political Ideologies, 21(2), 1-22.

Laclau, E. (2005). On populist reason. Verso.

Lisi, M. (2019). Parties, citizens and the Eurozone crisis. In M. E. Cavallaro \& K. Kornetis (Eds.), Rethinking democratisation in Spain, Greece and Portugal (pp. 151-178). Palgrave Macmillan.

Lisi, M., \& Borghetto, E. (2018). Populism, blame shifting and the crisis: Discourse strategies in Portuguese political parties. South European Society and Politics, 23(4), 405-427.

Lisi, M., Llamazares, I., \& Tsakatika, M. (2019). Economic crisis and the variety of populist response. West European Politics, 42(6), 1284-1,309.

Manucci, L., \& Weber, E. (2017). Why The Big Picture Matters: Political and Media Populism in Western Europe since the 1970s. Swiss Political Science Review, 23(4), 313-334. https://doi.org/10.1111/spsr.12267

McKibben, C. (2020). Populism on the periphery of democracy. Critical Review of International Social and Political Philosophy, 1-21, Epub ahead of print. https://doi.org/10.1080/13698230.2020.1799159

Mény, Y., \& Surel, Y. (2000). Par le peuple, pour le peuple. Fayard.

Mudde, C. (2017). Populism: An ideational approach. In C. Rovira Kaltwasser, P. Taggart, P. Ochoa Espejo, \& P. Ostiguy (Eds.), The Oxford handbook of populism (pp. 27-47). Oxford University Press.

Neves, J. (2010). Nacionalismo e Comunismo em Portugal. Tinta da China.

Orriols, L., \& León, S. (2020). Looking for Affective Polarisation in Spain: PSOE and Podemos from Conflict to Coalition. South European Society and Politics, 25, 351-379.

Pappas, T. S. (2019). Populism and liberal democracy. Oxford University Press.

Ramiro, L., \& Gomez, R. (2017). Radical-left populism during the Great Recession. Political Studies, 65(1), 108-126.

Rico, G., Guinjoan, M., \& Anduiza, E. (2017). The emotional underpinnings of populism. Swiss Political Science Review, 23(4), 444-461.

Roberts, K. M. (2017). Populism and political parties. In C. Rovira Kaltwasser, P. Taggart, P. Ochoa Espejo, \& P. Ostiguy (Eds.), The Oxford handbook of populism (pp. 517-534). Oxford University Press.

Rodrik, D. (2018). Populism and the economics of globalization. Journal of International Business Policy, 1, 12-33.

Rooduijn, M. (2014). The mesmerising message. Political Studies, 62(4), 726-744.

Rooduijn, M., \& Pauwels, T. (2011). Measuring populism. West European Politics, 34(6), 1272-1,283.

Sanders, K. B., Berganza, R., \& de Miguel, R. (2017). Spain: Populism from the far right to the emergence of Podemos. In T. Aalberg, F. Esser, C. Reinemann, J. Stromback, \& C. de Vreese (Eds.), Populist political communication in Europe (pp. 249-260). Routledge.

Schmuck, D., \& Hameleers, M. (2019). Closer to the people. Information, Communication \& Society, 23(10), 1531-1,548.

Schwörer, J. (2021). Less populist in power? Government \& Opposition, 1-23, Epub ahead of print. https://doi.org/10.1017/ gov. 2021.2

Silva, F. C., \& Vieira, M. B. (2018a). Populism as a Logic of Political Action. European Journal of Social Theory, $22(4), 497-512$. https://doi.org/10.1177/1368431018762540

Silva, F. C., \& Vieira, M. B. (2018b). Populism and the Politics of Redemption. Thesis Eleven, 149, 10-30. https://doi.org/10. $1177 / 0725513618813374$

Torcal, M. (2014). The decline of political trust in Spain and Portugal. American Behavioral Scientist, 58(2), $1542-1567$.

Weber, M. (1958). The protestant ethic and the spirit of capitalism. Scribner.

\section{SUPPORTING INFORMATION}

Additional supporting information may be found in the online version of the article at the publisher's website.

How to cite this article: da Silva, F. C., Manucci, L., \& Veloso Larraz, D. (2022). Populism and nationalism revisited: A comparative study of the Spanish and Portuguese New Left. Nations and Nationalism, 1-13. https://doi.org/10.1111/nana.12817 